\title{
均質溶液からの 8 -キノリノール・クロム塩の沈殿 クロムの重量分析への応用
}

(昭和 43 年 9 月 19 日受理)

$$
\text { 北野貢*1 } \cdot \text { 山形喜一郎*2 } \cdot \text { 山崎豊*1 }
$$

均質沈殿法によって 8-キノリノール・クロム塩の沈殿を生成させ，この沈殿を乾燥秤量してクロムの重量分析を行なった。 クロム $20 \mathrm{mg}$ を含む試料溶液 $100 \mathrm{ml}$ に $3 \%$ オキシン $(8-キ$ オリノール)酢酸溶液 $20 \mathrm{~m} l$, 尿素 $15 \mathrm{~g}$ を加え全液量 $200 \mathrm{ml}$ と する。 $95^{\circ} \mathrm{C}$ で 2 時間加熱すると， $p \mathrm{H}$ は 5.7〜6.0になる。この $p \mathrm{H}$ で $\mathrm{Cr}\left(\mathrm{C}_{8} \mathrm{H}_{8} \mathrm{ON}\right)_{3}$ なる組成を持つ結晶性クロムオキシン 塩が定量的に沈殿する。この沈殿をグラスフィルター(1 G 4)でロ過し, 温水で洗浄後, $105^{\circ} \mathrm{C} て ゙ 1$ 時間乾燥し秤量する。かルシ ウム, マグネシウム, 塩化物, 硝酸塩, 硫酸塩, リン酸塩は妨害しない。

\section{1 緒言}

オキシン(8-キノリノール)は約 80 年前に合成されて以来，多 くの研究者によって広範囲にわたる金属の分離，ならびに重量・ 容量分析法が検討開拓され, 現在では分析化学上重要な試薬の一 つとなっている。オキシンによって定量される金属の種類はきわ めて多いが1)2)，クロムについてはオキシンによって重量分析的に 定量された報告がなく，現在までに Austin によるつぎの報告が みられるだけである。

1938 年 Austin ${ }^{3}$ はクロム試料溶液に水酸化ナトリウム-酢酸ア ンモニウムの存在下でオキシンを添加し, $\mathrm{Cr}\left(\mathrm{C}_{9} \mathrm{H}_{6} \mathrm{ON}\right)_{3}$ の組成 をもつ難溶性沈殿をつくったが定量的な結果はえられなかった。

著者らは Austin の操作法を追試し, クロムオキシン塩の沈殿 条件について検討を加えた結果， $p \mathrm{H}$ 值と加熱時間を適当に選択 することによって定量的に沈殿することを見つけた。さらにこの 操作に尿素による均質沈殿法を応用してクロムオキシン塩の良好 な結晶性沈殿生成に成功し, クロムを重量分析的に正確に定量す る方法を確立したのでこれらの結果について報告する。

\section{2 試薬}

ク口ム試料溶液: 特級硝酸ク口ム結晶 $\mathrm{Cr}\left(\mathrm{NO}_{3}\right)_{3} \cdot 9 \mathrm{H}_{2} \mathrm{O} 15.0$ $\sim 15.4 \mathrm{~g}$ を水に溶解して $1 l$ とする。クロム含量の决定は容量分 析法4によった。

$3 \%$ オキシン酢酸溶液: 試薬特級オキシン $30 \mathrm{~g}$ を氷酢酸 120 $\mathrm{m} l$ で加温溶解したのち水でうすめて $1 l$ とする。

$0.1 \mathrm{~N}$ チオ硫酸ナトリウム溶液：特級チオ硫酸ナトリウム結晶

*1 Mitsugu KItano, Yutaka YAmazakI 金沢大学教育学 部化学教室, 金沢市丸の内

*2 Kiichiro YAMAGATA 石川県理科センター，金沢市緑ヶ 丘

1) R. Berg, "Die Analytische Verwendung von o-Oxychinoline(oxin) und seiner Derivate ", Enke, Stuttgart (1938) $2 \mathrm{Ed}$.

2) R. G. W. Hollingshead, "Oxine and its Derivatives", Butterworths Sci. Pub. London, Vol. I, II (1954); II, IV (1956).

3) E. Taylor-Austin, Analyst, 63, 710(1938).

4) I. M. Kolthoff, E. B. Sandell, “Textbook of Quanntitative Inorganic Analysis", John Wiley and Sons, New York(1952) 3 Ed., p. 690.
$\mathrm{Na}_{2} \mathrm{~S}_{2} \mathrm{O}_{3} \cdot 5 \mathrm{H}_{2} \mathrm{O} 25 \mathrm{~g}$ を水に溶解して $1 l$ とする。その溇度は $0.5 \mathrm{~N}$ 真素酸カリウム標準溶液で慓定した。

$0.5 \mathrm{~N}$ 臭素酸カリウム標準溶液: 特級自素酸カリウムを $150^{\circ} \mathrm{C}$ で乾燥し，その $13.831 \mathrm{~g}$ を特級臬化カリウム $50 \mathrm{~g}$ とともに水に 溶解して $1 l$ とする。

酢酸アンモニウム, 尿素, その他の試薬：いずれも特級試薬を 用いた。

\section{3 操 作 法}

クロム $20 \mathrm{mg}$ を含む弱酸性試料溶液 $100 \mathrm{ml}$ を $300 \mathrm{ml}$ のコ ニカルビーカーにとり，6N アンモニア水を水酸化クロムの沈殿 が生ずるまで滴下し，ついで硫酸数滴を加える。これを $70^{\circ} \mathrm{C} に$ 加温して，3\% オキシン酢酸溶液 $20 \mathrm{ml}$, および尿素 $15 \mathrm{~g}$ を水 に溶して添加し全液量 $200 \mathrm{~m} l$ とする。ビーカーを湯浴上で $95^{\circ} \mathrm{C}$ で 2 時間加熱すると反応液の $p \mathrm{H}$ は $5.7 \sim 6.0$ に上昇し, 茶褐色 の結晶性クロムオキシン塭の沈殿が生成する。この沈殿を 5〜10 分放置熟成しグラスフィルター(1 G 4)でロ過, 温水で 6 回洗浄後 $105^{\circ} \mathrm{C}$ で 1 時間乾嬠する。デシケーター中で 40 分冷却後秤量す る。

沈殿の組成は $\mathrm{Cr}\left(\mathrm{C}_{9} \mathrm{H}_{6} \mathrm{ON}\right)_{3}$ で，クロムへの換算率は

$$
\frac{\mathrm{Cr}}{\mathrm{Cr}\left(\mathrm{C}_{\theta} \mathrm{H}_{6} \mathrm{ON}\right)_{3}} \times 100=10.67(\%)
$$

として計算定量する。

\section{4 実験および結果}

\section{1 定量条件の設定}

4.1.1 Austin 法の検討: Austin はクロムオキシン塩生成法 としてつぎの操作を提案している。クロム $20 \mathrm{mg}$ を含む試料溶 液を $70^{\circ} \mathrm{C}$ に加温し， $3 \%$ オキシン酢酸溶液 $20 \mathrm{ml}, 1 \mathrm{~N}$ 水酸化 ナトリウム溶液 $20 \mathrm{ml}, 4 \mathrm{~N}$ 酢酸アンモニウム溶液 $20 \mathrm{ml}$ を加え 1 分間煮沸する。30 分放置しグラスフィルター(1 G 4)で口過, 温 水で洗浄後 $105^{\circ} \mathrm{C}$ で 1 時間乾燥し称量する(以下 Austin 法と略 称する)。

この操作法による Austin 自身の実験結果では(沈殿したクロ ム/全ク口ム)の比(以下沈殿生成率と略記する) は平均 $97.6 \%$ と 報告されており，著者らが同じ操作で追試を行なった結果も平均 $98.6 \%$ (表 2 参照)であって，この操作法では定量的な結果がえら れない。 


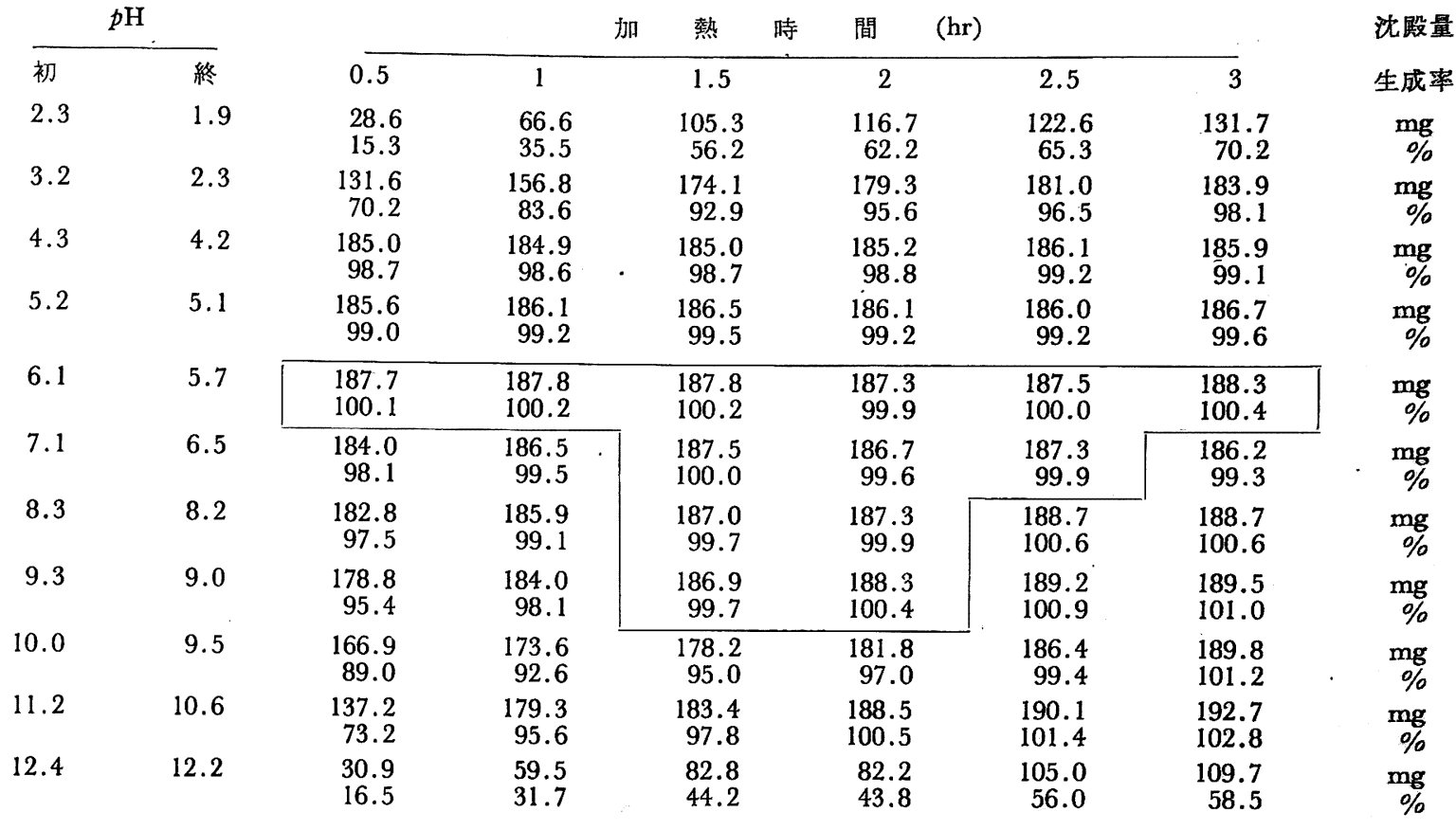

注 $\mathrm{Cr}$ 採取量 $20.14 \mathrm{mg} \approx \mathrm{Cr}$ オキシン塩 $187.5 \mathrm{mg} . \square \rightarrow \pm\left\{\begin{array}{l}0.4 \% \\ 0.7 \mathrm{mg}\end{array}\right.$

追試実験中, 反応液の $p \mathrm{H}$ 変化を追うと, オキシン溶液添加後 $p \mathrm{H} 3.80 \rightarrow$ 水酸化ナトリウム溶液・酢酸アンモニウム溶液添加後 $p \mathrm{H} 5.50 \rightarrow$ 反応終了時 $p \mathrm{H} 5.45$ となっており, この $p \mathrm{H}$ で 1 分 間煮沸して $98 \%$ 前後の沈殿生成染に達するわけである。

4.1.2 pH と加熱時間の影響: オキシン塩沈殿生成は反応時 の $p \mathrm{H}$ や加熱条件によって大きく影響される5)。著者らは Austin 法で定量的な結果がえられない理由として, Austin 法の定量条件 が沈殿生成の最適条件からはずれているためであると考え， $p \mathrm{H}$ と加熱時間について詳細に検討を加えた。

クロム試料溶液の 各試料ごとにオキシン酢酸溶液を加えたの ち, それぞれ $p \mathrm{H}$ を調節し, 加熱反応させて沈殿生成它行なった。 $p \mathrm{H}$ 值は 2〜12 の範囲について, また加熱条件は $80^{\circ} \mathrm{C} て ゙ 30$ 分 〜3 時間の範囲について実験を行ない, そのさいの沈殿生成率を 表 1 亿示す。表中黒枠で囲んだ範囲が定量的に沈殿する反応条件 である。

この実験の結果, 最適 $p \mathrm{H}$ 值は 5.7〜6.0であり, この $p \mathrm{H}$ で $80^{\circ} \mathrm{C}, 1$ 時間加熱すると定量的にオキシン塩沈殿が生成すること がわかる。

しかしながら，この反応の途中でしばしば未反応のオキシンが 油状となって浮き, これが沈殿を污染するためか沈殿粒の呈色, 粒度が不均一であり, また沈殿が器壁に付着しやすいなどの欠点 がある。この点を改良し良好な結晶性沈殿をえるためにつぎのよ うに尿素による均質沈殿法を試みた。

4.1 .3 均質沈殿法6)7の採用: 反応溶液に尿素を加えて加熱し ゆっくりと $p \mathrm{H}$ を上昇させると良好な沈殿がえられる。クロムオ キシン塩沈殿生成にこの操作(均質沈殿法)を採用するさいには,

5) 日本分析化学会編, “新分析化学講座(第 6 巻) 有機試薬 による分離分析法(下)”，共立出版(1958)第 1 章(本島健 次執筆).

6) H. H. Willard, N. K. Tang, J. Am. Chem. Soc., 59, 1190(1937).
定量的に沈殿生成をするよう, 反応溶液を $p \mathrm{H}$ 5.7〜 6.0 の範囲 内で相当時間加熱するための配虑が必要である。このためつぎの ように尿素添加量を種々変えて $p \mathrm{H}$ の上昇する状況を調べた。

クロム試料溶液に $3 \%$ オキシン酶酸溶液 $20 \mathrm{ml}$, 尿素 $5 \sim 20 \mathrm{~g}$ を加え全液量 $200 \mathrm{ml}$ とする。このときの初 $p \mathrm{H}$ は 3.8 であっ た。これを $95^{\circ} \mathrm{G}$ で加熱すると図 1 のように $p H$ か゚上昇する。

尿素 $15 \mathrm{~g}$ を用いて $95^{\circ} \mathrm{C}$ に加熱すると，加熱開始後 1 時䦓で $p \mathrm{H}$ 5.7〜6.0 の範囲に入り，かなりの時間この定量 $p \mathrm{H}$ 域内に とどをる。この結果から尿素使用量 $15 \mathrm{~g}$ を採用した。

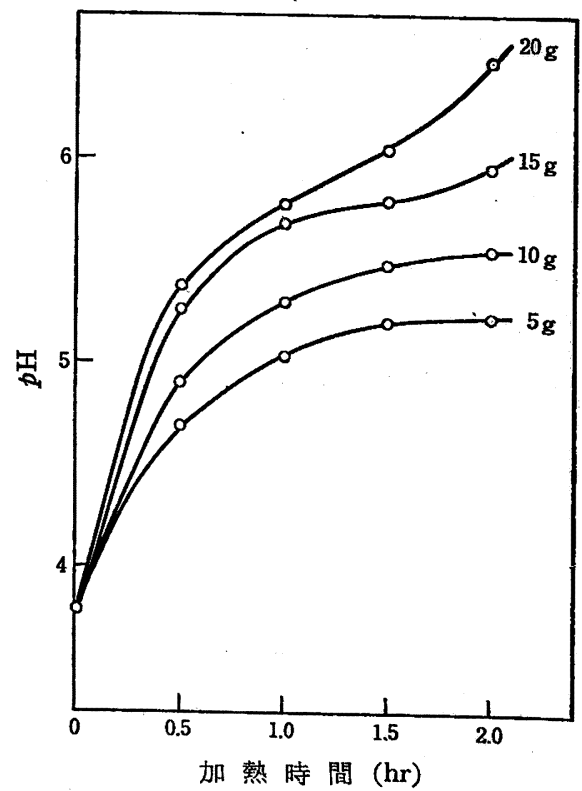

四 1 尿素使用量と $p H$ 上昇状況(全液量 $200 \mathrm{ml}$ )

7) 日本分析化学会編, “新分析化学講座(第 5 巻)有譏試薬 による分離分析法(上)”，共立出版 (1958)第 3 章(摹目清 
この方法によると良好な外観を有する絬晶性沈殿が生成し，こ の沈殿は器壁に付着することなく, 口過洗浄も容易である。

\section{2 定量値の比較}

Austin 法(従来法)および均質沈殿法(本法)を用いてクロム才 キシン塩沈殿生成によるクロム定量を行なった絬果をつぎの表 2 に示す。

表 2 オキシン塩沈殿によるクロム定量值

(A) Austin 法(従来法)

$\begin{array}{cccc}\begin{array}{c}\text { クロ採取量 } \\ (\mathrm{mg})\end{array} & \begin{array}{c}\text { 沈殿重量 } \\ (\mathrm{mg})\end{array} & \begin{array}{c}\text { クロム定量值 } \\ (\mathrm{mg})\end{array} & \begin{array}{c}\text { 沈殿生成率 } \\ (\%)\end{array} \\ 20.14 & 184.5 & 19.82 & 98.4 \\ 20.14 & 185.5 & 19.94 & 98.9 \\ 20.14 & 186.8 & 20.06 & 99.6 \\ 20.14 & 185.2 & 19.91 & 98.8 \\ 20.14 & 183.5 & 19.71 & 97.9\end{array}$

注 平均值士平均相対誤差 $98.6 \pm 0.4(\%)$

（B）均質沈殿法(本法)

$\begin{array}{cccc}\begin{array}{c}\text { クロ公採取量 } \\ (\mathrm{mg})\end{array} & \begin{array}{c}\text { 沈殿重量 } \\ (\mathrm{mg})\end{array} & \begin{array}{c}\text { クロ公定量值 } \\ (\mathrm{mg})\end{array} & \begin{array}{c}\text { 沈殿生成率 } \\ (\%)\end{array} \\ 20.14 & 187.2 & 20.11 & 99.8 \\ 20.14 & 187.2 & 20.11 & 99.8 \\ 20.14 & 187.6 & 20.15 & 100.0 \\ 20.14 & 187.8 & 20.17 & 100.2 \\ 20.14 & 187.5 & 20.14 & 100.0\end{array}$

注 平均值士平均相対誤差 $100.0 \pm 0.1(\%)$

均質沈殿法によると定量的な結果を与えるのみならず，沈殿の 外観も良好である。

\section{3 定量結果の検討}

4.3.1 沈殿の乾燥温度と時間: 本法によってえられた沈殿を $105^{\circ} \mathrm{C}$ に乾燥し，その重量を 30 分ごとに测定したところ 1 時間 以内で恒量となった(表 3 )。

またこの沈殿は吸湿性はほとんどない(結果略)。

表 3 オキシン塩乾燥時間と重量变化 乾燥温度： $105^{\circ} \mathrm{C}$

乾 燥 時 間 (min)

30

60

90

120

150
重 量 変 化(mg)

\begin{tabular}{ll}
\hline 例 1 & 例 2 \\
181.5 & 181.1 \\
181.1 & 181.0 \\
181.0 & 180.9 \\
181.0 & 180.7 \\
181.1 & 180.7
\end{tabular}

4.3.2 沈殿の組成: 本法によってえられた沈殿の組成は, Austin 法によってえられる沈殿と同じく $\mathrm{Cr}\left(\mathrm{C}_{9} \mathrm{H}_{6} \mathrm{ON}\right)_{3}$ なる組 成であった。このことはつぎのようにして確かめた。

沈殿中のクロム分の定量：オキシン塩をルツボ中に科りとり， 強熱して酸化クロムとして重量分析する。その絬果を表 4 に示す。 沈殿中のオキシン分の定量8): オキシン塩を塩酸で分解し, 生 じたオキシンを一定量の $0.5 \mathrm{~N}$ 臭素酸カリウム溶液で臭素化し， 残存した臭素酸カリウムをヨウ化カリウムと $0.1 \mathrm{~N}$ チオ硫酸ナト リウム溶液で逆滴定する。その結果を表 5 に示す。

8) 日本分析化学会編, “新分析化学講座(第 6 巻)有機試薬 による分離分析法(下)”，共立出版(1958)p. 14 .
表 4 オキシン塩中のクロム分率の測定

$\begin{array}{cccc}\begin{array}{c}\text { オキシン住採 } \\ \text { 取量 }(\mathrm{mg})\end{array} & \begin{array}{c}\text { 強䓡後 } \\ \left(\mathrm{Cr}_{2} \mathrm{O}_{3}\right)(\mathrm{mg})\end{array} & \begin{array}{c}\text { 同左中の } \\ \mathrm{Cr} \text { 值 }(\mathrm{mg})\end{array} & \begin{array}{c}\text { オキシン塩中 } \\ \text { のクム }\end{array} \\ 409.4 & 64.1 & 43.8 & 10.70 \\ 423.6 & 66.8 & 45.7 & 10.79 \\ 439.3 & 68.8 & 46.9 & 10.68 \\ 454.6 & 70.0 & 47.8 & 10.51\end{array}$

注 計算值 $\frac{\mathrm{Cr}}{\mathrm{Cr}\left(\mathrm{C}_{9} \mathrm{H}_{6} \mathrm{ON}\right)_{3}} \times 100=10.67(\%)$

表 5 オキシン塩中のオキシン分率の測定 $\begin{array}{ccc}\begin{array}{c}\text { オキシン程採取量 } \\ (\mathrm{mg})\end{array} & \begin{array}{c}\text { オキシン定量值 } \\ (\mathrm{mg})\end{array} & \begin{array}{c}\text { 塩中のオキシン } \\ (\%)\end{array} \\ 61.4 & 54.8 & 89.3 \\ 61.2 & 54.5 & 89.1 \\ 69.9 & 62.3 & 89.1 \\ 84.9 & 75.5 & 88.9 \\ 89.4 & 80.2 & 89.7\end{array}$

注 計算偭 $\frac{\left(\mathrm{C}_{8} \mathrm{H}_{7} \mathrm{ON}\right)_{3}}{\mathrm{Cr}\left(\mathrm{C}_{8} \mathrm{H}_{8} \mathrm{ON}\right)_{3}} \times 100=89.3(\%)$

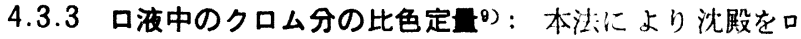
別したのた，口液を烝発ザラで源縮し硫酸打よび硝酸を加えて白 煙処理を行なったのち, シフェニルカルバシドを加えて発学させ， 口液中に残存するクロム分を比色定是した。

その結果を表 6 に示す。これによると口液中のク口ム分は僅少 であり，4.2 の定量結果が重量分析的に湍足なものであることが わかる。

表 6 口液中のクロム分の比色定量

$\begin{array}{cccc}\begin{array}{c}\text { クロム採取量 } \\ (\mathrm{mg})\end{array} & \begin{array}{c}\text { 沈殿 重 } \\ (\mathrm{mg})\end{array} & \begin{array}{c}\text { 口量 } \\ \text { ロ液中のクロ } \\ \text { ム }(\mathrm{mg})\end{array} & \begin{array}{c}\text { クム定量值 } \\ (\mathrm{mg})\end{array} \\ 20.14 & 187.5 & 0.037 & 20.14 \\ 20.14 & 187.7 & 0.066 & 20.16 \\ 20.14 & 187.6 & 0.038 & 20.15 \\ 20.14 & 188.0 & 0.067 & 20.19 \\ 20.14 & 188.1 & 0.079 & 20.20\end{array}$

\section{4 共存物質の影響}

共存物質の影響について検討を行なった。その結果を表 7 に示 す。本法によるとカルシウム，マグネシウム，塩化物，硝酸塩， 硫酸塭, リン酸塩は妨害しない。

表 7 共 存 物 質 の 影 響

\begin{tabular}{|c|c|c|c|c|}
\hline $\begin{array}{l}\text { 口八採取 } \\
\text { 量 (mg) }\end{array}$ & \multicolumn{2}{|c|}{$\begin{array}{c}\text { 共存物質と重量 } \\
\text { (mg) }\end{array}$} & $\begin{array}{c}\text { クロ公㫡量 } \\
\text { 值 }(\mathrm{mg})\end{array}$ & $\begin{array}{c}\text { 沈殿生成率 } \\
(\%)\end{array}$ \\
\hline 19.87 & $\mathrm{NaCl}$ & 1000 & 19.96 & 100.5 \\
\hline 19.87 & $\mathrm{Ca}\left(\mathrm{NO}_{3}\right)_{2}$ & 1000 & 19.90 & 100.2 \\
\hline 19.87 & $\mathrm{Mg}\left(\mathrm{NO}_{3}\right)_{2}$ & 1000 & 19.95 & 100.4 \\
\hline 19.87 & 酒石酸 $\mathrm{NaK}$ & 1000 & 20.03 & 100.8 \\
\hline 19.87 & $\mathrm{~K}_{2} \mathrm{SO}_{4}$ & 1000 & 19.86 & 100.0 \\
\hline 19.87 & $\mathrm{Na}_{2} \mathrm{HPO}_{4}$ & 1000 & 19.92 & 100.3 \\
\hline
\end{tabular}

\section{5 定量範囲}

本法によるクロム定量を 5〜30 mg のクロム量について実験 し, 表 8 に示す絬果をえた。この筙四のク口ムは定量的に沈殿す る。

9) E. B. Sandell, "Colorimetric Determination of Traces of Metals", Interscience Pub. Inc., New York(1950) 2 Ed., p. 265 , 
表 8 各ク口ム採取量とその定量值

$\begin{array}{cccc}\begin{array}{c}\text { クロム採取量 } \\ (\mathrm{mg})\end{array} & \begin{array}{c}\text { 沈殿重量 } \\ (\mathrm{mg})\end{array} & \begin{array}{c}\text { クロム定量值 } \\ (\mathrm{mg})\end{array} & \begin{array}{c}\text { 採取量と定量 } \\ \text { 値の差 }\end{array} \\ 4.91 & 45.4 & 4.88 & -0.03 \\ 4.91 & 45.0 & 4.84 & -0.07 \\ 9.92 & 91.9 & 9.89 & -0.03 \\ 9.92 & 91.3 & 9.83 & -0.09 \\ 19.84 & 184.5 & 19.84 & 0 \\ 19.84 & 184.8 & 19.85 & +0.01 \\ 29.84 & 278.1 & 29.88 & +0.04 \\ 29.84 & 278.3 & 29.92 & +0.08\end{array}$

5 結語

クロムオキシン塩の 沈殿生成条件を詳細に゙ 調べた結果, $p \mathrm{H}$ 5.7〜6.0 において定量的にクロムが沈殿することを知った。さ らに尿素による均質沈殿法を応用し，そのさい $p \mathrm{H}$ 值が上述の範 囲内にくるよう反応を行なわせると，良好な結晶性沈殿が定量的 にえられた。この結果を総合してオキシンによるクロム定量法と して 3(操作法)に記した方法を提案する。この方法で 5〜30 mg のクロムが小さい誤差で重量分析できる。

(1966 年 4 月, 日本化学会第 19 年会講演)

\section{デカモリブドヒ酸 (V) の合成およびその性質}

(昭和 43 年 8 月 15 日 受理)

$$
\text { 井上英 武・伊藤 博 夫*1 }
$$

強酸性溶液中で五酸化二ヒ素とパラモリブデン酸フンモニウムとから黄色生成物をえた。この生成物は元素分析值およびX線回 折からデカモリブドヒ酸(V)であることを明らかにした。

この化合物の性質を，可視吸収スペクトルを用いた勾配比法，電位差滴定，電導度滴定などにより検討した結果，本化合物が $\mathrm{H}_{3}\left[\mathrm{AsO}_{4} \cdot\left(\mathrm{Mo}_{2} \mathrm{O}_{6}\right)_{5}\right]$ の化学式を有するへテロポリ酸であること，さらに本化合物がつぎの機構で生成すると考えれば，各種の実 験結果をよく説明できることがわかった。

$$
\begin{aligned}
& \mathrm{H}_{3} \mathrm{AsO}_{4}+10 \mathrm{H}_{2} \mathrm{MoO}_{4} \stackrel{\mathrm{H}^{+}}{\rightleftarrows} \mathrm{H}_{3} \mathrm{AsO}_{4}+5 \mathrm{H}_{4} \mathrm{Mo}_{2} \mathrm{O}_{8} \stackrel{\mathrm{H}^{+}}{\rightleftarrows} \mathrm{H}_{3}\left[\mathrm{AsO}_{4} \cdot\left(\mathrm{Mo}_{2} \mathrm{O}_{6}\right)_{5}\right] \\
& \text { [1] } \\
& \text { [2] } \\
& \uparrow \mid \mathrm{H}^{+} \\
& \text {[3] } \\
& \mathrm{H}_{3} \mathrm{AsO}_{4}+\left(\mathrm{MoO}_{3}\right)_{x}
\end{aligned}
$$

\section{1 緒言}

一般にヘテロポリ酸またはその塩は古くから知られ，その中で もモリブデンまたはタングステンのヘテロポリ酸およびその塩は 代表的なものであり，その合成法，構造，性質さらに用途などは かなりよく研究されている1 3。しかしながらヒ素をへテロ原子 とするモリブデンのヘテロポリ酸とその塩の合成法, 性質, 用途 などの詳細は報告されておらず，リンをへテロ原子とするへテロ ポリ酸と同様な化合物4)が生成すると推定されているにすぎな い。わずかに知られている例としてドデカモリブドヒ酸 $(\mathrm{V})$ があ る。この化合物はヒ素をへテロ原子とするへテロポリ酸の中でも っとも安定な化合物といわれ，七素の比色定量によく使用されて おり，その定量法に関する報告が多い。

一方，Brown ら5はヒ素をへテロ原子とするへテロポリタング

*1 Hidemu Inoue, Hiroo Ito 東严合成化学工業株式会 社研究所, 名古屋市港区船見町

1) P. Souchay, "Seventh International Conference on Coordination Chemistry", Butterworths(1963)p. 61 .

2) 柴田村治, 化学と工業, 11, 322(1958).

3) K. F. Jahr, J. Fuchs, Angew. Chem., 78, 725(1966).

4) J. W. Mellor, "A Comprehensive Treatise on Inorganic and Theoretical Chemistry $\mathbb{X}$ ", Longmans, Green and Co.(1929) p. 206.

5) D. H. Brown, A. J. Hyde, J. Chem. Soc., 1962, 3186.
ステン酸としてドデカタングストヒ酸 (而)を合成し，その性質に ついて検討した結果を報告している。

著者らはいままで知られていないヒ素(V)はモりブデンのへテ ロポリ酸であるデカモリブドヒ酸 ( V )を合成し, 興味ある知見を えたのでここに報告する。

\section{2 実}

\section{験}

\section{1 デカモリブドヒ酸(V)の合成方法}

パラモリブデン酸アンモニウム(和光純薬製試薬特級) $31.5 \mathrm{~g}$ $(25.5 \mathrm{mmol})$ を $60 \mathrm{ml}$ の温水に溶解し，これを，三酸化二七素 (和光試薬特級) $1.5 \mathrm{~g}(7.4 \mathrm{mmol})$ を $30 \%$ 硝酸 $30 \mathrm{ml}$ に還流溶解 した液中へ徐々に滴下する。この場合三酸化二と素は酸化され， ヒ酸として溶解している。滴下開始時に生成じた黄色沈殿はかき まぜるとただちに消失するが，その後滴下をつつけてゆくとしだ いに消失しなくなる。滴下終了後室温まで放冷し，元られた黄色 沈殿を口過し，さらに洗液が酸性を呈しなくなるまで水洗する。 その後, 真空乾燥器中で $60^{\circ} \mathrm{C}, 6$ 時間乾燥した結果, 約 $22 \mathrm{~g}$ の黄色生成物をえた(表 1 , 試料 $\mathbf{C}$ 参照)。

\section{2 試料中のモリブテンおよび七秦の分析}

2.1 の合成法でえられた試料約 $1 \mathrm{~g}$ をはかりとり，5N 水酸化 ナトリウム $3 \mathrm{ml}$ 中に溶解した液を，交献ににしたがってヒ素

6）たとえば，高木誠司，“定量分析の実験と討算 第 2 巻”; 共立出版 (1967) p. 336. 